\title{
FUNCTIONAL STRATEGIES FOR CERTAIN GROWTH STAGES OF CORN IN RESPONSE TO ENVIRONMENTAL FACTORS: IRRIGATION AND PLANTING DATE MANAGEMENT
}

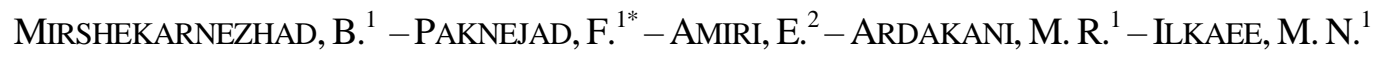 \\ ${ }^{I}$ Department of Agronomy, Karaj Branch, Islamic Azad University, Karaj, Iran \\ (e-mails:bob_mirshekar@yahoo.com; farzadpaknejad@yahoo.com; \\ mreza.ardakani@gmail.com;mn64_ilkaee@yahoo.com) \\ ${ }^{2}$ Department of Agriculture, Lahijan Branch, Islamic Azad University, Lahijan, Iran \\ (e-mail:eamiri57@yahoo.com) \\ *Corresponding author \\ e-mail: farzadpaknejad@yahoo.com; phone: +98-263-418-3942; fax: +98-263-418-3928 \\ (Received $7^{\text {th }}$ Jul 2018; accepted $31^{\text {st }}$ Aug 2018)
}

\begin{abstract}
Agriculture in arid areas with inadequate water supply enquires the right cognition of evapotranspiration related to water application. In this research a single-cross hybrid of maize (S.C. 704), under the split plot experiment based on randomized complete block design was selected for cultivation in 2015 and 2016 years. The experimental treatments were set up in three planting dates: $21^{\text {st }}$ April, $11^{\text {th }}$ May and $31^{\text {st }}$ May, and four irrigation regimes: $\mathrm{I}_{100}(100 \%), \mathrm{I}_{80}(80 \%), \mathrm{I}_{60}(60 \%)$ and $\mathrm{I}_{40}(40 \%)$ of the estimated evapotranspiration (ET). The results showed a drastic reduction by 44 to $49 \%$ in grain yield under low irrigation regime $\left(\mathrm{I}_{40}\right)$ compared with full irrigation regime $\left(\mathrm{I}_{100}\right)$, respectively. Irrigation water use efficiency based on grain yield $\left(1.39\right.$ and $\left.1.20 \mathrm{~kg} / \mathrm{m}^{3}\right)$ and biological yield $\left(4.79\right.$ and $\left.4.53 \mathrm{~kg} / \mathrm{m}^{3}\right)$ was the highest in $\mathrm{I}_{40}$ for each year, respectively. Corns planted earlier fulfilled silking-maturity duration faster than corns planted at the end of planting window as a result of reducing final yield potential. Under drought stress situation of this experiment it was shown that with long season hybrid, grain yield and irrigation efficiency can be improved by timely applications of planting dates and irrigation levels.

Keywords: drought stress, evapotranspiration, grain yield, silking-maturity duration, water use efficiency
\end{abstract}

\section{Introduction}

In many parts of the world where agriculture is important, crops usually encounter a large variation in water supply during their growing seasons. Thus water deficit is a major constraint to crop production, even in humid environments (Soltani and Sinclair, 2012). Corn biomass can be reduced with deficit irrigation and any loss in biomass can result in the final yield reduction. When water for irrigation is limited the goal should be integrated to maximize net income per unit water used rather than per land unit. Thus, the limited irrigation strategy meets this concept by establishing water economy as well as achieving efficiencies (Fereres and Soriano, 2007).

Many crops have lower yield in response to water stress at vegetative and reproductive stages. Deficit irrigation involves an appropriate scheduling of irrigation because crop sensitivity to water deficit changes with the phenological stages (Istanbulluoglu, 2009). Water stress affects crop growth and productivity in many ways. Most of the responses have negative effect on production but crops have different and often complex mechanisms against water scarcity (Kirda et al., 1999). Many results implied that crop water use efficiency was an intrinsic system sensitive to climate change. These findings indicated that crops had the resilience by adjusting water use 
efficiency (Zhang et al., 2015). Planting date analysis showed that a delayed planting date caused a decrease in average yield of $55 \%$ for the rainfed and $21 \%$ for the irrigated conditions for all hybrids (Soler et al., 2007).

Weather conditions that are optimal for maize production are likely to be less predictable in future due to variability in weather conditions and may have infrastructural effects on the stage of maturity at harvest (Blignaut et al., 2009). Manipulations that increase carbohydrate supply to developing grains during drought stress not only decrease abortion but can also increase grain yield (Morison et al., 2008). Anthesis-silking interval is a predictor of seed set in many maize cultivars when affected by stresses at flowering (Edmeades et al., 2000). Grain yield can be reduced by decreasing yield components like ear size, number of kernel per ear and kernel weight. Claassen and Shaw (1970) observed that water stress at silking stage and pollination process resulted in kernel number reduction, while stress during or after silking reduced kernel weight.

Whether or not, one of the confrontational challenges for us is how we can adapt the crop system processes to the future environmental changes. However the challenge still remains of low crop yield and sometimes crop failure due to poor choice of planting date. Thus with the aim of optimizing water and corn productivities in relevant to optimum ET maintenance, this research explores the key agronomic practices such as taking right planting dates and well-apprised water requirements at critical stages of corn growth cycle.

\section{Materials and methods}

\section{Study area}

The arid and semi-arid region of Karaj in Alborz province, Iran $\left(35^{\circ} 50^{\prime} \mathrm{N}, 51^{\circ} 0^{\prime} \mathrm{E}\right.$, $1312 \mathrm{~m}$ a.s.1.) is demarcated as one of the most important area for both food and forage crops cultivation. Maize production is possible only under irrigated condition (Fig. 1). The average rainfall of this site is less than $250 \mathrm{~mm}$ per annum. Such diversity of geographical features plays a dominant role in determining the topography, climate and plant species present in the region.

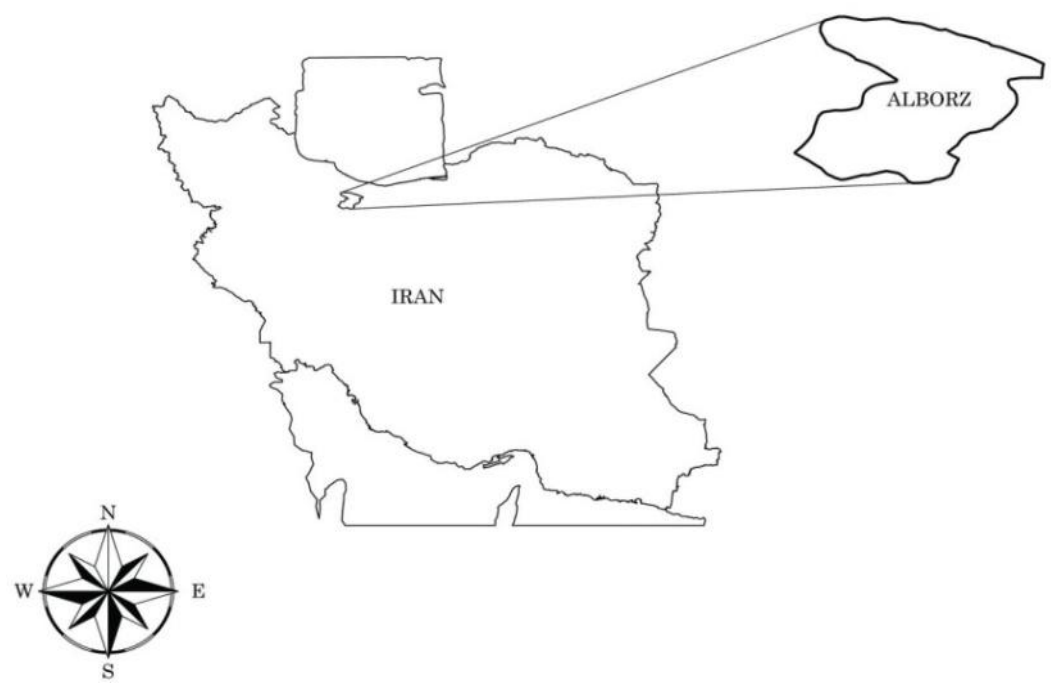

Figure 1. Geographical location of Alborz province in Iran map 


\section{Soil characteristics and agronomic management}

Primarily the research field plowed and disked regularly to pulverize the clods. Thereafter, a Hiller-Furrower was employed to create planting furrows in the seedbed. According to the United States Department of Agriculture classification (USDA), the territory soil of the site is classified as a Typic Haplocambid (Mirkhani et al., 2010). The soil samples were tested for some physical and chemical compositions in both successive years (Table 1). The soil texture was determined as clay loam throughout the experiment.

Table 1. Some physical and chemical compositions of soil in the experimental site

\begin{tabular}{c|c|c|c|c|c|c|c|c}
\hline Year & Soil depth & $\mathbf{E C}(\mathbf{d s} / \mathbf{m})$ & $\mathbf{S p}(\%)$ & $\mathbf{p H}$ & $\mathbf{N}(\boldsymbol{\%})$ & $\mathbf{P}(\mathbf{m g} / \mathbf{k g})$ & $\mathbf{K}(\mathbf{m g} / \mathbf{k g})$ & $\mathbf{O . C} .(\%)$ \\
\hline $2015-16$ & $0-30$ & 2.53 & 39.8 & 8.3 & 0.08 & 6.3 & 203 & 0.71 \\
\hline $2016-17$ & $0-30$ & 1.58 & 38.2 & 8.5 & 0.09 & 7.0 & 207 & 0.75 \\
\hline
\end{tabular}

The field of research site was arranged in three blocks of 12 plots each, with an even space between them so that each plot involved six rows of $5 \mathrm{~m}$ in length and $75 \mathrm{~cm}$ spacing apart. After testing the seeds with fungicide (Tebuconazole), applying dry method, three-four seeds spaced in created grooves on the top of the furrows. The plots were kept weed-free by hand weeding and Rotavator applying between rows. Nitrogen application in the form of urea at a rate of $150 \mathrm{~kg} / \mathrm{ha}$, top-dressed at two stages of corn life cycle. Ultimately, thinning at five-leaf stage of seedlings was down up to a final density of 8 plants per square meter.

\section{Experimental layout and crop assessment}

The field experiments took place in the research farm of the College of Agriculture and Natural Resources, University of Tehran, located in Karaj, Iran (35 $45^{\circ}$ N, $50^{\circ} 57^{\prime}$ E, $1293 \mathrm{~m}$ a.s.l.). The split-plot experiment based on a randomized complete block design with three replicates carried out in 2015-16 and 2016-17 cropping seasons. The experimental treatments in three planting dates in main plots were scheduled for $21^{\text {st }}$ April, $11^{\text {th }}$ May and $31^{\text {st }}$ May, and four irrigation levels consisting of $100 \%, 80 \%, 60 \%$ and $40 \%$ of (ET) in sub plots were summarized as $\mathrm{I}_{100}, \mathrm{I}_{80}, \mathrm{I}_{60}$ and $\mathrm{I}_{40}$. The amount of evaporated water through transpiration was estimated by Equation 1 (FAO, 1977).

$$
E T_{c}=K_{c} \times E T_{o}
$$

where, $\mathrm{ET}_{\mathrm{c}}$ is crop evapotranspiration $(\mathrm{mm} / \mathrm{d}), \mathrm{ET}_{0}$ is reference evapotranspiration $(\mathrm{mm} / \mathrm{d})$ and $\mathrm{K}_{\mathrm{c}}$ is crop coefficient. The calculation of $\mathrm{ET}_{0}$ was determined in $\mathrm{mm}$ by recording weekly evaporation data obtained from the class A evaporation pan, located in synoptic weather station of Karaj. The amount of water evaporated during a period corresponds with the decrease in water depth of the pan in that period. On the basis of FAO Penman-Monteith Method, $\mathrm{K}_{\mathrm{c}}$ values $(0.3,1.2$ and 0.3-0.6) for three corn growth stages were defined as $\mathrm{K}_{\mathrm{c} \text { ini }}, \mathrm{K}_{\mathrm{c} \text { mid }}$, and $\mathrm{K}_{\mathrm{c} \text { end }}$, under the given condition (Allen et al., 1998). Water requirements for individual plots measured in gallon weekly then converted to liter per week. The final volume of water application for irrigating each plot was computed using Equation 2: 


$$
\ln =\frac{0.623 \times A \times K e \times E T 0}{I E}
$$

where, $I_{n}$ denotes the volume of irrigation water in gallons per week, 0.623 is the equation constant, A stands for plot area (sq. ft.), Kc represents crop coefficient, $\mathrm{ET}_{0}$ is the reference evapotranspiration in $(\mathrm{mm})$ per day. IE at the rate of 80 percent is the indicator of irrigation efficiency that finally expressed in decimal i.e. (0.80) (Howell, 2003). The total of irrigation volumes that computed for two consecutive years are presented in the following timetable (Table 2). All plots were irrigated uniformly until the plants were completely established. The irrigation treatments started when the plants were at the 6-7 leaf growth stage using water flow meter.

Table 2. The weekly reference evapotranspiration $\left(E T_{o}\right)$ and water volumes applied after starting irrigation regimes

\begin{tabular}{c|c|c|c|c|c|c}
\hline \multirow{2}{*}{ Year } & \multirow{2}{*}{$\begin{array}{c}\text { Total weekly } \\
(\mathbf{m m})\end{array}$} & \multirow{2}{*}{$\begin{array}{c}\text { Number of } \\
\text { irrigations }\end{array}$} & \multicolumn{4}{|c}{ Total water volume applied for irrigation } \\
\cline { 4 - 6 } & & & $\mathbf{I}_{\mathbf{1 0 0}}$ & $\mathbf{I}_{\mathbf{8 0}}$ & $\mathbf{I}_{\mathbf{6 0}}$ & $\mathbf{I}_{\mathbf{4 0}}$ \\
\hline $2015-16$ & 27.1 & 7 & 7482 & 5986 & 4489 & 2993 \\
\hline $2016-17$ & 29.5 & 8 & 7490 & 5992 & 4494 & 2996 \\
\hline
\end{tabular}

When the ears were at full physiological maturity stage with an evident black layer of the grains, whole plants from two adjacent rows in each plot including ears were harvested near the ground level to determine total dry matter. The plants separated into leaf, stem and ear fractions. Then leaf and stem samples separately put into a labeled paper bag and were placed in a dehydrator to dry at $75^{\circ} \mathrm{C}$ until constant mass. For grain yield, 10 plants from the remaining half-plot were harvested and measured for weight of ears per plant and number of grains per ear. Finally, irrigation water use efficiency (IWUE) based either on grain yield (GY) or biological yield (BY) was calculated by Equations 3 and 4:

$$
\begin{aligned}
& I W U E=(G Y / I) \\
& I W U E=(B Y / I)
\end{aligned}
$$

where, GY is grain yield ( $\mathrm{kg} / \mathrm{ha}), \mathrm{BY}$ is biological yield $(\mathrm{kg} / \mathrm{ha})$, and I is the amount of applied irrigation water $\left(\mathrm{m}^{3}\right)$. It is important to emphasize, in the case of precipitation the amount of added water to the evaporation pan was measured daily during pan readings to account for estimating reference evapotranspiration. Also harvest index (HI) estimated by the ratio of harvested grains to total shoot dry matter by Equation 5:

$$
H I=(G Y / B Y) \times 100
$$

\section{Statistical analysis}

Analysis of variance (ANOVA) employed for two years datasets using PROC GLM in SAS program (V., 9.1). Growing degree days (GDDs) accumulation measured by summing the number of daily accumulated heat degrees in a day, obtained by the 
average of the maximum (T-Max) and minimum (T-Min) temperatures $\left({ }^{\circ} \mathrm{C}\right)$ for the day, minus the base temperature (T-Base) which is established as $10{ }^{\circ} \mathrm{C}$ for corn development. T-Max and T-Min are limited to $30^{\circ} \mathrm{C}$ and $10{ }^{\circ} \mathrm{C}$, respectively. All tables and graphs were designed by excel software. Significant differences among means were compared by Duncan's multiple range test.

\section{Results}

\section{Weather conditions during corn life cycle}

The maximum and minimum air temperatures, rainfall and relative humidity data were prepared based on Karaj auto weather station reports in the vicinity of the research site. The seasonal maximum and minimum air temperatures were approximately the same for both cropping seasons (Fig. 2). The total rainfall of $12.1 \mathrm{~mm}$ in 2016-17, was remarkably less than of $33.5 \mathrm{~mm}$ which mainly occurred in April during 2015-16. Therefore, due to more rainfall and wetter condition in 2015-16, the number of irrigations and the rates of estimated water volume in various irrigation regimes in 2016-17 were slightly greater than in 2015-16.

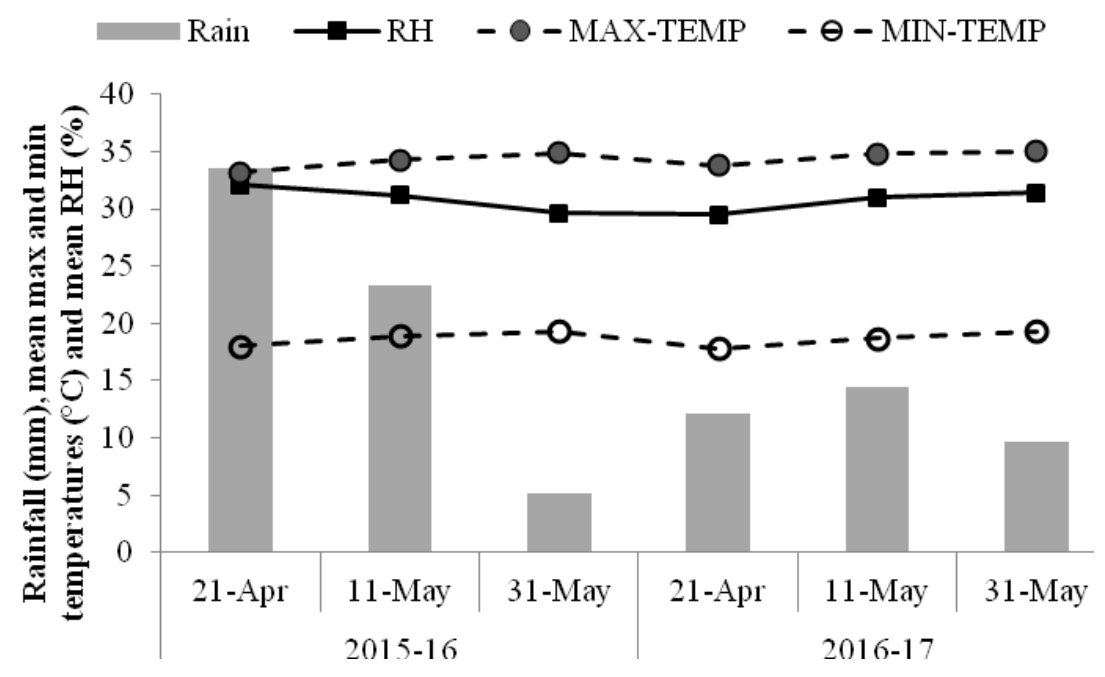

Figure 2. Seasonal average of climatic data during corn maturity in 2015-16 and 2016-17

\section{Silking-maturity interval across various planting dates}

Silking-maturity interval varies when crops are planted either early or late. Grain yield is in direct contact with kernel weight and GDD requirements. As planting delays, temperature and radiation levels become increasingly critical for yield determination. Hence, if corn is stressed during silking to maturity period, inadequate GDD levels can form prematurely preventing additional dry matter accumulation (Table 3).

Corn growth stage development can vary according to planting date. An earlyplanting corn may develop through growth stages slower than a late-planting corn. However, apart from early or late planting date, there is a transition between silking to physiological maturity time during which kernels are filled. In addressing the results of Table 3, silking to maturity duration by late-planted corns occurred at a slower pace (42 and 43 days) after the accumulation of 684 and 621 GDDs in each year, respectively 


$$
-6174 \text { - }
$$

(Fig. 3). In contrast, early-planted corns with longer vegetative growth stage fulfilled silking to maturity period rapidly (40 and 39 days) after the accumulation of 739 and 711 GDDs in both years, respectively (Fig. 4).

Table 3. Some growth and climate data during silking-maturity interval in corn

\begin{tabular}{c|c|c|c|c|c|c}
\hline Year & $\begin{array}{c}\text { Reproductive } \\
\text { stage }\end{array}$ & $\begin{array}{c}\text { Planting date } \\
(\mathbf{P D})\end{array}$ & $\begin{array}{c}\text { Mean temp } \\
\left({ }^{\circ} \mathbf{C}\right)\end{array}$ & $\begin{array}{c}\text { Radiation } \\
\left(\mathbf{M J} / \mathbf{m}^{2} / \mathbf{d a y}\right)\end{array}$ & $\begin{array}{c}\mathbf{E T}_{\mathbf{c}} \\
(\mathbf{m m})\end{array}$ & $\begin{array}{c}\text { GDDs } \\
\left({ }^{\circ} \mathbf{C}-\text { day }\right)\end{array}$ \\
\hline \multirow{3}{*}{$2015-16$} & \multirow{2}{*}{ Silking to } & $\mathrm{PD}_{1}$ & 28.0 & 30 & 425 & 739 \\
& maturity & $\mathrm{PD}_{2}$ & 28.8 & 26 & 454 & 734 \\
& & $\mathrm{PD}_{3}$ & 29.6 & 23 & 493 & 684 \\
\hline \multirow{3}{*}{$2016-17$} & \multirow{2}{*}{ Silking to } & $\mathrm{PD}_{1}$ & 28.3 & 28 & 396 & 711 \\
& maturity & $\mathrm{PD}_{2}$ & 28.4 & 27 & 441 & 697 \\
& & $\mathrm{PD}_{3}$ & 29.1 & 24 & 507 & 621 \\
\hline
\end{tabular}

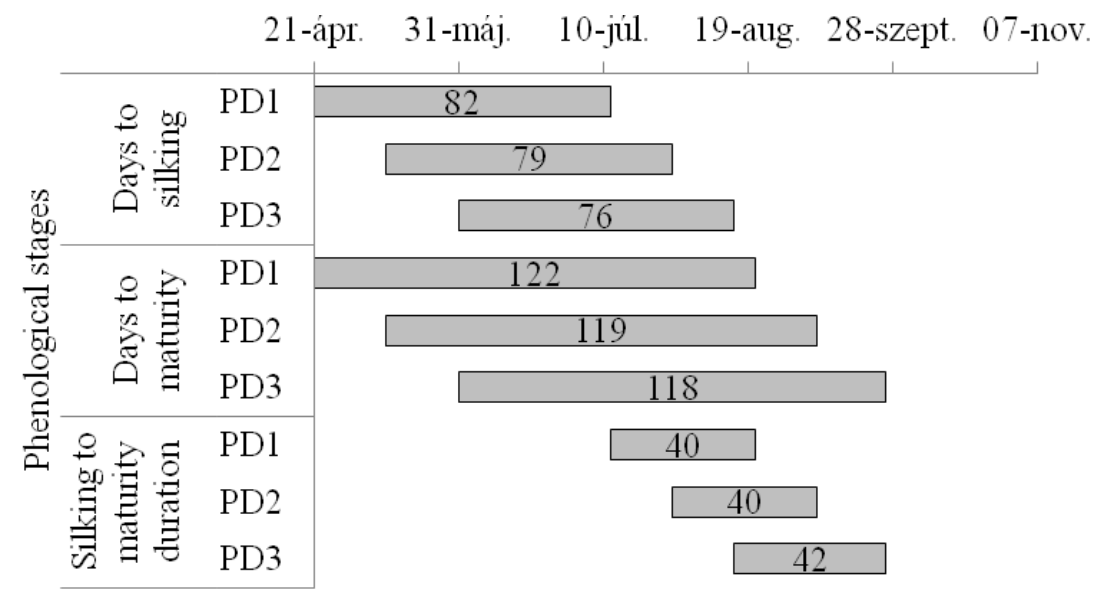

Start date $\square$ Duration (day)

Figure 3. Days from silking to maturity completion in three planting dates (2015-16)

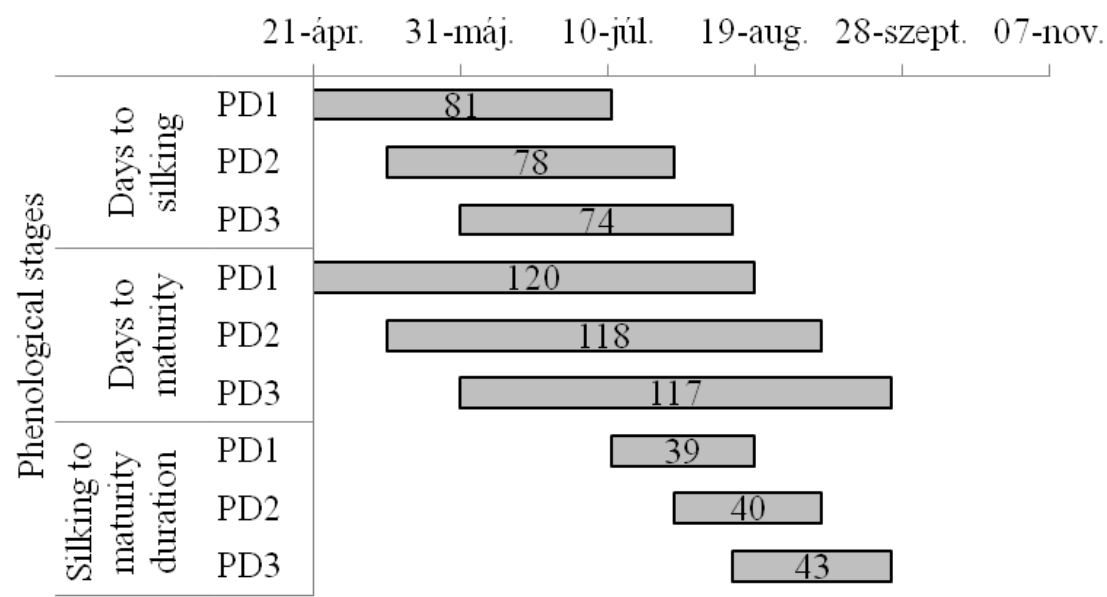

Start date $\square$ Duration (day)

Figure 4. Days from silking to maturity completion in three planting dates (2016-17) 


\section{Mean comparisons and significance level of interactions}

As planting date (PD) delayed and water amount restricted from non-stress treatment $\left(\mathrm{I}_{100}\right)$ to full-stress treatment $\left(\mathrm{I}_{40}\right)$, there was a drastic reduction by 44 and $49 \%$ in $\mathrm{GY}$ during both 2015-16 and 2016-17, respectively (Tables 4 and 5). However the reduction of $\mathrm{GY}$ in response to late-planting date was more evident in the second year. Incidentally, the same tragedy occurred with BY which made a reduction by 17 and $22 \%$ in $\mathrm{I}_{40}$ compared to $\mathrm{I}_{100}$ in both years, respectively. There was also a decrement in the range of 32 to $35 \%$ for harvest index (HI) against irrigation levels in both years, respectively.

Table 4. Means comparison of main traits and significance level of interactions in corn for 2015-16

\begin{tabular}{|c|c|c|c|c|c|c|c|c|c|}
\hline \multicolumn{2}{|c|}{ Corn Traits } & $\begin{array}{c}\text { Grain } \\
\text { yield } \\
\text { (kg/ha) }\end{array}$ & $\begin{array}{c}\text { Biological } \\
\text { yield } \\
\text { (kg/ha) }\end{array}$ & $\begin{array}{c}\text { Ear } \\
\text { weight } \\
\text { (kg/ha) }\end{array}$ & $\begin{array}{c}\text { Kernel } \\
\text { abortion } \\
(\%)\end{array}$ & $\begin{array}{c}\text { 1000- } \\
\text { KW } \\
\text { (gr) }\end{array}$ & $\begin{array}{c}\text { Harvest } \\
\text { index } \\
(\%)\end{array}$ & $\begin{array}{c}\mathrm{IWUE}_{\mathrm{GY}} \\
\left(\mathrm{kg} / \mathrm{m}^{3}\right)\end{array}$ & $\begin{array}{c}\mathrm{IWUE}_{\mathrm{BY}} \\
\left(\mathrm{kg} / \mathrm{m}^{3}\right)\end{array}$ \\
\hline \multirow{4}{*}{ Irrigation levels } & $\mathrm{I}_{40}$ & $4150.3^{d}$ & $14354.6^{\mathrm{d}}$ & $5177.7^{\mathrm{d}}$ & $18.00^{\mathrm{a}}$ & $165.55^{\mathrm{c}}$ & $28.76^{\mathrm{d}}$ & $1.39^{\mathrm{a}}$ & $4.79^{\mathrm{a}}$ \\
\hline & $\mathrm{I}_{60}$ & $5038.6^{c}$ & $14885.7^{\mathrm{c}}$ & $5773.9^{c}$ & $15.44^{\mathrm{b}}$ & $180.33^{\mathrm{c}}$ & $33.76^{\mathrm{c}}$ & $1.12^{\mathrm{b}}$ & $3.31^{b}$ \\
\hline & $\mathrm{I}_{80}$ & $6446.1^{b}$ & $16643.8^{\mathrm{b}}$ & $7873.1^{\mathrm{b}}$ & $13.66^{\mathrm{b}}$ & $203.78^{b}$ & $38.53^{\mathrm{b}}$ & $1.08^{\mathrm{b}}$ & $2.78^{\mathrm{c}}$ \\
\hline & $\mathrm{I}_{100}$ & $7364.4^{\mathrm{a}}$ & $17398.2^{\mathrm{a}}$ & $8613.7^{\mathrm{a}}$ & $10.55^{\mathrm{c}}$ & $239.44^{\mathrm{a}}$ & $42.16^{\mathrm{a}}$ & $0.98^{c}$ & $2.32^{\mathrm{d}}$ \\
\hline \multirow{3}{*}{ Planting dates } & $\mathrm{PD}_{1}$ & $6613.6^{\mathrm{a}}$ & $16724.6^{\mathrm{a}}$ & $7599.6^{\mathrm{a}}$ & $13.83^{\mathrm{a}}$ & $211.50^{\mathrm{a}}$ & $39.02^{\mathrm{a}}$ & $1.32^{\mathrm{a}}$ & $3.49^{\mathrm{a}}$ \\
\hline & $\mathrm{PD}_{2}$ & $5484.2^{\mathrm{b}}$ & $15853.3^{b}$ & $6547.6^{\mathrm{b}}$ & $13.50^{\mathrm{a}}$ & $212.67^{\mathrm{a}}$ & $34.20^{\mathrm{b}}$ & $1.09^{\mathrm{b}}$ & $3.31^{\mathrm{b}}$ \\
\hline & $\mathrm{PD}_{3}$ & $5151.8^{b}$ & $14883.8^{c}$ & $6431.6^{\mathrm{b}}$ & $15.91^{\mathrm{a}}$ & $167.67^{\mathrm{b}}$ & $34.19^{\mathrm{b}}$ & $1.02^{\mathrm{b}}$ & $3.10^{\mathrm{c}}$ \\
\hline \multicolumn{2}{|c|}{$\mathrm{PD} \times \mathrm{IR}(\mathrm{DMRT}<0.05)$} & ns & ns & $*$ & ns & ns & ns & ns & ns \\
\hline
\end{tabular}

Means within the same column followed by the same letters are not significantly different $(\mathrm{p}<0.05)$. $\mathrm{KW}=$ Kernel weight; $\mathrm{IWUE}_{\mathrm{GY}} / \mathrm{IWUE}_{\mathrm{BY}}=$ Irrigation water use efficiency of grain yield/biological yield; $\mathrm{PD}=$ Planting Date; $\mathrm{IR}=$ Irrigation

Table 5. Means comparison of main traits and significance level of interactions in corn for 2016-17

\begin{tabular}{|c|c|c|c|c|c|c|c|c|c|}
\hline \multicolumn{2}{|c|}{ Corn traits } & $\begin{array}{c}\text { Grain } \\
\text { yield } \\
\text { (kg/ha) }\end{array}$ & $\begin{array}{c}\text { Biological } \\
\text { yield } \\
(\mathrm{kg} / \mathrm{ha})\end{array}$ & $\begin{array}{c}\text { Ear } \\
\text { weight } \\
\text { (kg/ha) }\end{array}$ & $\begin{array}{c}\text { Kernel } \\
\text { abortion } \\
(\%)\end{array}$ & $\begin{array}{c}\text { 1000- } \\
\text { KW } \\
\text { (gr) }\end{array}$ & $\begin{array}{c}\text { Harvest } \\
\text { index } \\
(\%)\end{array}$ & $\underset{\left(\mathbf{K g} / \mathbf{m}^{3}\right)}{\operatorname{IWUE}_{\mathbf{3}}}$ & $\begin{array}{c}I{ }^{\prime} E_{B Y} \\
\left(\mathrm{~kg} / \mathrm{m}^{3}\right)\end{array}$ \\
\hline \multirow{4}{*}{ Irrigation levels } & $\mathrm{I}_{40}$ & $3589.60^{\mathrm{d}}$ & $13563.90^{\mathrm{d}}$ & $4849.00^{\mathrm{d}}$ & $28.44^{\mathrm{a}}$ & $151.4^{\mathrm{d}}$ & $26.34^{\mathrm{d}}$ & $1.20^{\mathrm{a}}$ & $4.53^{\mathrm{a}}$ \\
\hline & $\mathrm{I}_{60}$ & $4597.20^{c}$ & $14689.70^{c}$ & $5808.20^{\mathrm{c}}$ & $22.44^{\mathrm{b}}$ & $171.4^{\mathrm{c}}$ & $31.25^{\mathrm{c}}$ & $1.02^{\mathrm{b}}$ & $3.27^{b}$ \\
\hline & $\mathrm{I}_{80}$ & $5860.00^{\mathrm{b}}$ & $15851.00^{\mathrm{b}}$ & $6936.00^{\mathrm{b}}$ & $15.22^{\mathrm{c}}$ & $197.4^{\mathrm{b}}$ & $37.00^{\mathrm{b}}$ & $0.98^{\mathrm{bc}}$ & $2.64^{\mathrm{c}}$ \\
\hline & $\mathrm{I}_{100}$ & $7099.10^{\mathrm{a}}$ & $17317.80^{\mathrm{a}}$ & $7927.60^{\mathrm{a}}$ & $11.11^{\mathrm{c}}$ & $245.3^{\mathrm{a}}$ & $40.96^{\mathrm{a}}$ & $0.95^{\mathrm{c}}$ & $2.31^{\mathrm{d}}$ \\
\hline \multirow{3}{*}{ Planting dates } & $\mathrm{PD}_{1}$ & $5770.30^{\mathrm{a}}$ & $15628.30^{\mathrm{a}}$ & $6617.40^{\mathrm{a}}$ & $18.00^{\mathrm{a}}$ & $203.58^{\mathrm{a}}$ & $36.28^{\mathrm{a}}$ & $1.13^{\mathrm{a}}$ & $3.25^{\mathrm{a}}$ \\
\hline & $\mathrm{PD}_{2}$ & $5168.00^{b}$ & $15601.20^{\mathrm{a}}$ & $6399.10^{\mathrm{ab}}$ & $18.42^{\mathrm{a}}$ & $188.50^{b}$ & $32.70^{\mathrm{b}}$ & $1.01^{\mathrm{b}}$ & $3.21^{\mathrm{ab}}$ \\
\hline & $\mathrm{PD}_{3}$ & $4921.10^{\mathrm{b}}$ & $14837.30^{\mathrm{b}}$ & $6124.10^{b}$ & $21.50^{\mathrm{a}}$ & $182.16^{\mathrm{b}}$ & $32.69^{\mathrm{b}}$ & $0.95^{\mathrm{b}}$ & $3.09^{\mathrm{b}}$ \\
\hline \multicolumn{2}{|c|}{$\mathrm{PD} \times \mathrm{IR}(\mathrm{DMRT}<0.05)$} & $* *$ & $\mathrm{~ns}$ & ns & ns & $*$ & $*$ & ns & ns \\
\hline
\end{tabular}

Means within the same column followed by the same letters are not significantly different $(p<0.05)$. $\mathrm{KW}=$ Kernel weight; $\mathrm{IWUE}_{\mathrm{GY}} / \mathrm{IWUE}_{\mathrm{BY}}=$ Irrigation water use efficiency of grain yield/biological yield; PD = Planting Date; $I R=$ Irrigation 
Irrigation water use efficiency (IWUE) at high irrigation level $\left(\mathrm{I}_{100}\right)$, was the lowest and at low irrigation level $\left(\mathrm{I}_{40}\right)$, was the highest. In consequence, the highest values of $\operatorname{IWUE}_{\mathrm{GY}}\left(1.39\right.$ and $\left.1.20 \mathrm{~kg} / \mathrm{m}^{3}\right)$ and the greatest values of $\operatorname{IWUE}_{\mathrm{BY}}(4.79$ and 4.53 $\mathrm{kg} / \mathrm{m}^{3}$ ) were recorded at $\mathrm{I}_{40}$ compared with $\mathrm{I}_{100}$ in both years, respectively. Earlyplanting date was prominent for holding the highest values of each trait except kernel abortion.

\section{Effect of water variability and planting date on grain yield}

Planting dates and irrigation levels interaction $(\mathrm{PD} \times \mathrm{IR})$ had significant effect ( $\mathrm{p}<0.01$ ) on grain yield (GY) in 2016-17 (Fig. 5). Corns that planted later under effect of limiting factors such as drought stress, poor levels of radiation as well as irrepressible changes in temperature and assimilate supply, formed kernels poor in size and quality. Whereas, early-planting corns $\left(\mathrm{PD}_{1}\right)$, produced more nutrient levels than $\mathrm{PD}_{2}$ or $\mathrm{PD}_{3}$ in exchange of full water application of $100 \% \mathrm{ET}_{\mathrm{c}}$. Consequential effects of these responses can find in bigger kernels which have been set during grain-fill stage as a result of grater final yield potential.

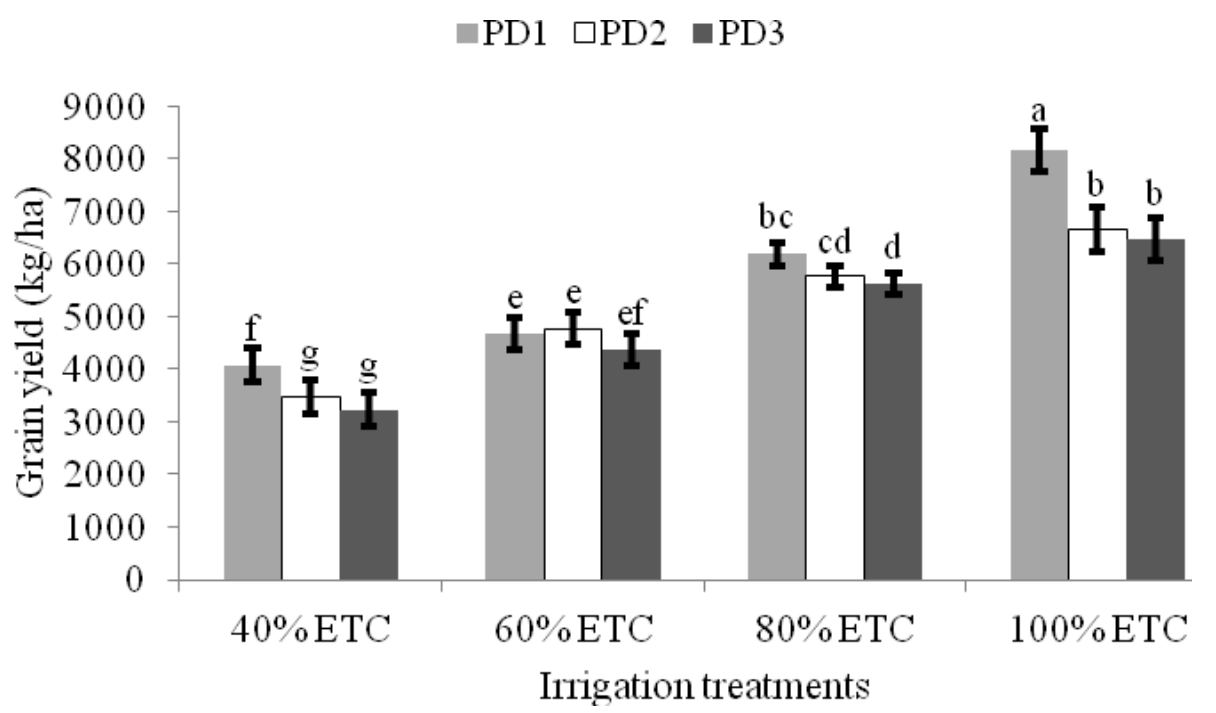

Figure 5. The interaction of planting dates and irrigation levels on grain yield in 2016-17. Different letters indicate significant difference $(p<0.01)$ based on DMRT test

\section{ET- function and management considerations of relevance}

The effects of the various weather conditions are incorporated into the reference evapotranspiration $\left(\mathrm{ET}_{0}\right)$ estimates. $\mathrm{ET}_{0}$ represents an index of climate demand and $\mathrm{K}_{\mathrm{c}}$ varies, predominately with the specific crop characteristics and only to a limited extends with climate (Allen et al., 1998). In particular, crop ET demand can vary according to the location, time of planting, soil texture and corn growth period. The values of $\mathrm{ET}_{0}$ and $\mathrm{ET}_{\mathrm{c}}$ were quite low at the initial period due to the less evaporation from the soil and plant surfaces and subsequently from transpiration through stomata in the early of the corn life cycle. Initially, the $\mathrm{ET}_{\mathrm{c}}$ values virtually followed constant trend at low fixed rates of $K_{c}(0.3)$, then peaked at 70-80 days after planting at the higher $K_{c}$ ranges $(1.2$ and 0.6) in mid and last terms of corn life cycle, respectively (Fig. 6). 


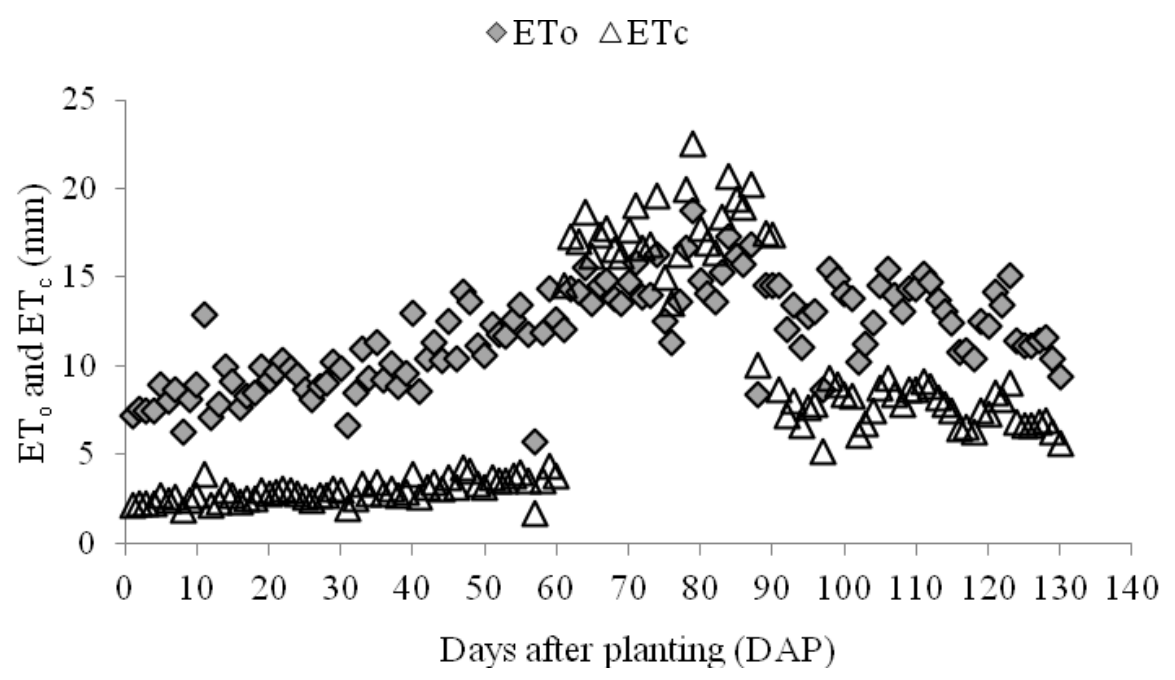

Figure 6. Reference and crop ET estimations based on FAO $\left(K_{c}\right)$ during corn maturity as a function of days after planting. ET $T_{0}$ is a climatic parameter expressing the evaporation power of the atmosphere; $E T_{c}$ refers to the evaporative demand from crops that are grown under the given climatic conditions

Crop ET-value was the highest at silking stage (R1) which occurred around 8082 days after planting (Fig. 7).

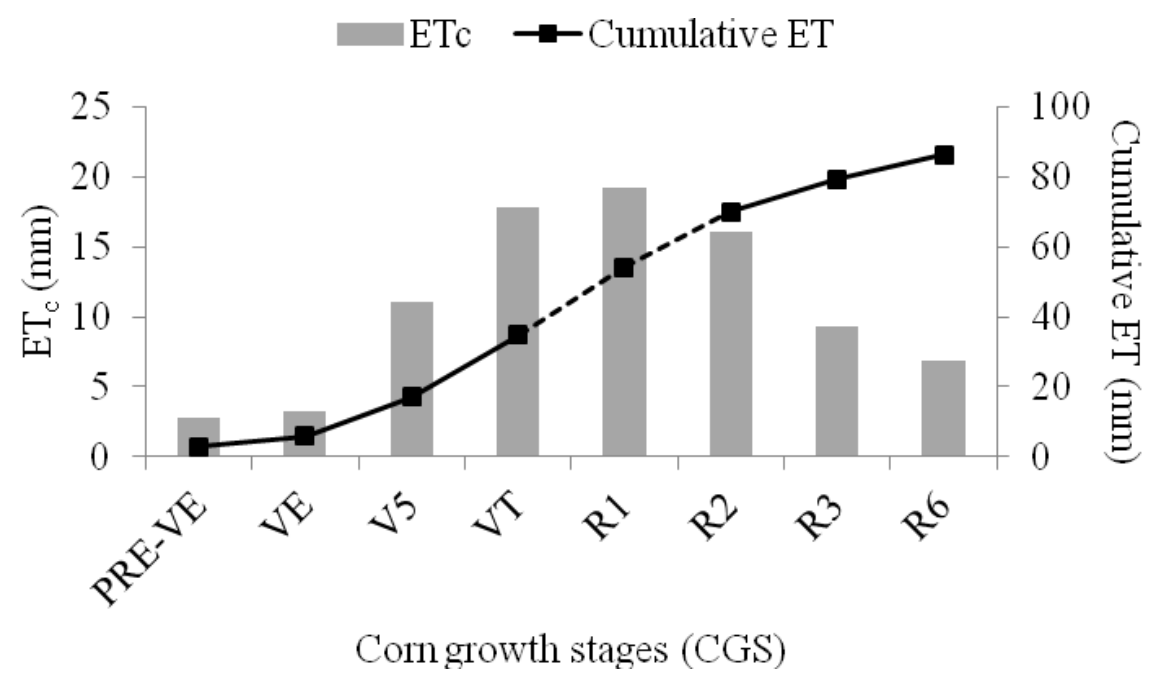

Figure 7. Crop ET and cumulative ET $(\mathrm{mm})$ variations in different corn growth stages, the dotted part represents the most critical time to water stress. PRE-VE = Pre emergence, VE = Emergence, $V 5=$ Fifth leaf visibility, $V T=$ Tasseling stage, $R 1=$ Silking stage, $R 2=$ Beginning grain fill, $R 3=$ Milk stage and $R 6=$ Physiological maturity

Regionally when irrigation applied in the common rate of ET demand, grain yield reduction is not directly related to ET and biomass reduction. When ET demand cumulatively increases from what is needed for crop longevity and substantially deficit irrigation occurs below the optimum ET level, it can be more devastating at tassel to grain-fill stage (VT to R2). Although overall grain yield will decline as biomass 
declines, effective deficit irrigation management can allow corn water stress to be managed so that HI does not decline. For this reason, planting corn early in the season with sufficient water supply in the soil and less water loss by evaporation can avoid irrigations which are surplus to requirements. In this experiment, irrigation efficiency based on GY was improved by $23 \%$ and $16 \%$ in $\mathrm{PD}_{1}$ compared to $\mathrm{PD}_{3}$ for both years, respectively. These results underlined the advantage of water management at certain growth stages to minimize corn negative physiological responses.

\section{Discussion}

Based on the findings, the effect of deficit irrigation on GY was greater than on total biomass, as reflected in low HI under deficit irrigation treatments. Our observation corroborated by those of (Payero et al., 2009; Chaichi et al., 2015). According to Fereres and Soriano (2007), as biomass production is tightly associated with ET, it represents that in the case of deficit irrigation plant capability in converting per unit of water to biomass will be improved through transpiration due to the proximity of wetter condition and cooler temperatures in the early of the growing season. Early-planted corns via earlier shading of soil surface with unrestricted accessibility to water resources have higher irrigation efficiency. In contrast late-planted corns due to loss of moisture increasingly below the optimum ET level and less demand for assimilate; produce smaller grains in relation to per mm of water application. Lower GYs were largely occurred as total biomass and harvest index decreased with delayed plantings (Tsimba et al., 2013). Instead, in cereals it may also result in beneficial redistribution of assimilate from storage to developing grains to increase HI under scarcer water condition (Yang et al., 2002). In spite of improving irrigation efficiency with water deficit in this experiment, AL-Kaisi and Xinhua (2003) reported that drought stress reduced the water use efficiency for the production of biological yield but somewhat increased it for the production of economical yield in maize. In general, there is not inordinate demand for water during corn developmental stages due to proximity of rainy season and minimal weed competition in the early stage of corn life cycle. As plant population increase, an early-planting date becomes more important. Thus in a waterlimited situation, planting long duration hybrids early in the season when the cumulative seasonal ET demand is low induced less yield penalty (Tsimba et al., 2013). Based on the soil type and ET demand, avoiding water stress around two weeks prior to pollination entering into two weeks after silking, can assure economical yields as a result of better seed set and less barren tips. The results obtained are in agreement with the ex-reports (Doorenbos and Kassam, 1979; Hatfield et al., 2015). Vegetative growth is strongly affected by water stress at different developmental stages. Short-duration irrigations during the rapid vegetative growth period caused 28 to $32 \%$ loss of final dry matter weight (Cakir, 2004). Fundamentally, GDDs are used to account for corn growth relative to temperature. Normally, corn requires approximately 600 to 800 GDDs to accomplish silking to maturity period. If unfavorable conditions exist it may take more time for late-planted corns to achieve this period with less GDDs accumulation than early-planted corns. Additionally, as planting delayed, radiation abatement and low GDDs accumulation became increasingly critical for kernels setting. Water stress during this time can delay silking, reduce pollination and lead to kernel abortion. These remarks compared with those who addressed silking to pollen shed or anthesis-silking 
interval responses to water stress (Herrero and Johnson, 1981; Westgate, 1994; Bolaños and Edmeades, 1996).

\section{Conclusion}

In conclusion, when corn planting occurs later in the season the source-sink limitations can avert loading and substantially grain yield losses in response to drought stress. Instead, corns that are planted earlier in the season tend to develop more gradually under more abundant of water supplies with definite number of GDDs accumulation. Reasons for this can help greater overall productivity with early-planting date. In the case of being in trouble for water supply, early planting date via holding optimum ET level and accelerating silking to maturity interval can avoid irrigations that are surplus to requirements. The irrigation water use efficiency and overall productivity of corn in this research improved through the assignment of early-planting date and deficit irrigation to the environmental and crop physiological limitations. Consequently, shifting planting date from common-planting date $\left(\mathrm{PD}_{2}\right)$ to an earlier date as well as deficit irrigation were integrated as the best adaptive strategies for Iran climate and other regions in the world with high evaporative ranges. Other adaptation strategy can prioritize by producer to select diverse hybrids of maize with high drought tolerance ratings.

\section{REFERENCES}

[1] Al-Kaisi, M. M., Xinhua, Y. (2003): Effects of nitrogen rate, irrigation rate and plant population on corn yield and water use efficiency. - Agronomy Journal 95: 1475-1482.

[2] Allen, R. G., Pereira, L. S., Raes, D., Smith, M. (1998): Crop Evapotranspiration Guidelines for Computing Crop Water Requirements. - FAO Irrigation and Drainage Paper 56. FAO, Rome.

[3] Blignaut, J., Urckermann, L., Aronson, J. (2009): Agriculture production's sensitivity to changes in climate in South Africa. - Journal of Science 105: 61-71.

[4] Bolaños, J., Edmeades, G. O. (1996): The importance of the anthesis-silking interval inbreeding for drought tolerance in tropical maize. - Field Crops Research 48: 65-80.

[5] Cakir, R. (2004): Effect of water stress at different development stages on vegetative and reproductive growth of corn. - Field Crops Research 89: 1-16.

[6] Chaichi, M. R., Nurre, P., Slaven, J., Rostamza, M. (2015): Surfactant application on yield and irrigation water use efficiency in corn under limited irrigation. - Crop Science 55: 386-393.

[7] Claassen, M. M., Shaw, R. H. (1970): Water deficit effects on corn. II. Grain components. - Agronomy Journal 62: 652-655.

[8] Doorenbos, J., Kassam, A. H. (1979): Yield Response to Water. - In: Johl, S. S. (ed.) Irrigation and Agricultural Development: Based on an International Expert Consultation, Baghdad Iraq. Pergamon Press, New York.

[9] Edmeades, G. O., Bolaños, J., Elings, A., Ribaut, J. M., Bänziger, M., Westgate, M. E. (2000): The Role and Regulation of the Anthesis-Silking Interval in Maize. - In: Westgate, M. E., Boote, K. (eds.) Physiology and Modeling Kernel Set in Maize. CSSA, Madison, WI, pp. 43-73.

[10] FAO (1977): Crop Water Requirement. - Irrigation and Drainage Paper No. 24. FAO, Rome.

[11] Fereres, E., Soriano, M. A. (2007): Deficit irrigation for reducing agricultural water use. Journal of Experimental Botany 58: 147-59. 
[12] Hatfield, J., Prueger, L., John, H. (2015): Temperature extremes: Effect on plant growth and development. - Weather and Climate Extremes 10: 4-10.

[13] Herrero, M. P., Johnson, R. R. (1981): Drought stress and its effects on maize reproductive systems. - Crop Science 21: 105-110.

[14] Howell, T. A. (2003): Irrigation Efficiency. - In: Stewart, B. A., Howell, T. A. (eds.) Encyclopedia of Water Science. Marcel Dekker, New York, pp. 467-472.

[15] Istanbulluoglu, A. (2009): Effects of irrigation regimes on yield and water productivity of safflower (Carthamus tinctorius L.) under Mediterranean climatic conditions. Agricultural Water Management 96: 1792-1798.

[16] Kirda, C., Moutonnet, P., Hera, C., Nielsen, D. R. (1999): Crop Yield Response to Deficit Irrigation. - Water Reports 22. FAO, Rome.

[17] Mirkhani, R., Roozitalab, N., Khaleghpanah, N., Rezaei, S. (2010): Physico-chemical characteristics and clay mineralogy composition of selected soils in arid and semiarid regions of Iran. - In: Extended Abstracts $21^{\text {st }}$, Australian Clay Minerals Conference, Brisbane, QLD, Australia, 5-8 Aug. 2010.

[18] Morison, J. I. L., Baker, N. R., Mullineaux, P. M., Davies, W. J. (2008): Improving water use in crop production phil. - Transactions of the Royal Society B 363: 639-658.

[19] Payero, J. O., Tarkalson, D. D., Irmak, S., Davison, D., Petersen, J. L. (2009): Effect of timing of a deficit-irrigation allocation on corn evapotranspiration, yield, water use efficiency and dry mass. - Agricultural Water Management 96: 1387-1397.

[20] Soler, C. M. T., Sentelhas, P. C., Hoogenboom, G. (2007): Application of the CSMCERES-Maize model for planting date evaluation and yield forecasting for maize grown off-season in a subtropical environment. - European Journal of Agronomy 27: 165-177.

[21] Soltani, A., Sinclair, T. R. (2012): Modeling Physiology of Crop Development, Growth and Yield. - CABI, Wallingford, UK.

[22] Tsimba, R., Edmeades, G. O., Millner, J. P., Kemp, P. D. (2013): The effect of planting date on maize: Phenology, thermal time durations and growth rates in a cool temperate climate. - Field Crops Research 150: 145-155.

[23] Westgate, M. E. (1994): Water status and development of the maize endosperm and embryo during drought. - Crop Science 34: 76-83.

[24] Yang, J. C., Zhang, J. H., Liu, L. J., Wang, Z. Q., Zhu, Q. S. (2002): Carbon remobilization and grain filling in Japonica/Indica hybrid rice subjected to post anthesis water deficit. - Agronomy Journal 94: 102-109.

[25] Zhang, J., et al. (2015): Responses of crop water use efficiency to climate change and agronomic measures in the semiarid area of Northern China. - PLoS ONE 10(9): e0137409. DOI: 10.1371/journal.pone.0137409. 